\title{
Empowering Leadership Dalam Peningkatan Kreativitas Karyawan
}

\author{
Santi Retno Sari ${ }^{1, *}$, Kumba Digdowiseiso ${ }^{1}$ \\ ${ }^{1}$ Fakultas Ekonomi dan Bisnis; Universitas Nasional; Jl.Sawo Manila Pasar Minggu Jakarta; \\ Telp 021 -7806700 e-mail: santiretnosari@gmail.com, kumba.digdo@civitas.unas.ac.id \\ * Korespondensi: e-mail: santiretnosari@gmail.com \\ Submitted: 05/01/2022; Revised: 12/01/2022; Accepted: 20/01/2022; Published: 31/01/2022
}

\begin{abstract}
The purpose of this study is to examine empowerment leadership and its dimensions, namely the dimensions of leading by example, coaching, participative decision making, informing and show concern and also include creative self-efficacy variables in influencing employee creativity. The study took the population of employees at three companies in the field of financial services located in Jakarta. The sample measurement technique uses the Slovin formula. From this calculation, a sample size of 159 employees was obtained. Intake of 159 samples taken by simple random sampling technique. The data analysis technique used to test the hypothesis was using multiple regression with SPSS 26. The results showed that increasing the practice of empowering leadership and creative self-efficacy of employees will increase employee creativity. The results of the influence of the five dimensions of empowerment leadership on employee creativity, only the leading by example dimension is proven to affect employee creativity. While the other four dimensions have no significant effect. The practical implication is that companies are expected to apply leadership that empowers employees and create programs to increase employee creative self-efficacy in an effort to increase employee creativity.
\end{abstract}

Keywords: Creative Self-Efficacy, Employee Creativity, Empowerment Leadership

\begin{abstract}
Abstrak
Tujuan Penelitian ini menguji kepemimpinan pemberdayaan beserta dimensinya yaitu dimensi leading by example, coaching, participative decision making, informing dan show concern serta memasukan juga variabel efikasi diri kreatif dalam mempengaruhi kreativitas karyawan. Penelitian mengambil populasi karyawan pada tiga perusahaan di bidang jasa keuangan yang berada di Jakarta. Teknik pengukuran sampel mempergunakan rumus Slovin. Dari perhitungan ini didapatkan ukuran sampel159 karyawan. Pengambilan 159 sampel diambil dengan teknik simple random sampling. Teknik analisis data untuk menguji hipotesis mempergunakan regresi berganda dengan SPSS 26 . Hasil menunjukkan bahwa peningkatan praktik kepemimpinan pemberdayaan dan efikasi diri kreatif karyawan akan meningkatkan kreativitas karyawan. Hasil dari pengaruh Lima dimensi kepemimpinan pemberdayaan terhadap kreativitas karyawan, hanya dimensi leading by example yang terbukti mempengaruhi kreativitas karyawan. Sedangkan emat dimensi lainnya tidak berpengaruh signifikan. Implikasi praktis dijabarkan bahwa perusahaan diharapkan menerapkan kepemimpinan yang memberdayakan karyawan dan membuat program peningkatan efikasi diri kreatif karyawan dalam usaha peningkatan kreativitas karyawan.
\end{abstract}

Kata kunci: Efikasi Diri Kreatif, Kreativitas Karyawan, Kepemimpinan Pemberdayaan 


\section{Pendahuluan}

Beberapa dekade ini, peningkatan ketertarikan terhadap pembahasan kreativitas makin marak. Masa pandemi Covid-19 yang menjadi cobaan terutama dalam dunia bisnis, memaksa perusahaan untuk pandai-pandai bertahan. Organisasi yang tangguh merupakan organisasi yang mampu beradaptasi dan terus berinovasi (Sari, 2017; Thawil dan Sari, 2018). Yang mana untuk penciptaan inovasi diperlukan kreativitas (Thawil dan Sari, 2018).

Kreativitas merupakan kegiatan dalam menemukan cara pandang baru, mencari dan mengembangkan ide baru untuk mengatasi masalah dan mencari peluang (Zimmerer dan Scarborugh, 1996). Pelaksanaan kreativitas di tempat kerja dapat berupa menghasilkan ide-ide orisinal yang bermanfaat dalam menangkap peluang dan mengatasi masalah di tempat kerja (Hughes dkk., 2018).

Konsep pemberdayaan kepemimpinan telah menarik perhatian dalam literatur kreativitas (Hughes dkk., 2018; Zhang dkk., 2018). Kepemimpinan pemberdayaan menunjukkan perilaku yang disengaja pemimpin untuk berbagi kekuasaan dengan karyawan dan untuk memberi mereka tanggung jawab tambahan dan kontrol atas pekerjaan mereka sendiri (Luthans, 2011). Kajian penelitian memberikan bukti bahwa kepemimpinan yang memberdayakan karyawan akan meningkatkan perilaku kreatif karyawan (Alfaris dan Zakiy, 2021; Martono, Wulansari dan Khoirudin, 2020). Untuk menciptakan dan meningkatkan kreativitias karyawan, dibutuhkan peran seorang pemimpin yang mampu memberdayakan bawahannya. Kemampuan pemberdayaan yang dilakukan pemimpin akan meningkatkan motivasi belajar dan kepercayaan kepada pemimpin. Sehingga karyawan optimal dalam mengekspresikan kreativitasnya di tempat kerja (Fitriani dan Wulansari, 2018).

Pemimpin pembedayaan mencoba untuk menciptakan konteks kerja di mana otonomi karyawan dan kebermaknaan kerja dapat didukung dan disokong (Zhang dkk., 2018). Literatur kepemimpinan pemberdayaan memperkenalkan dengan beberapa dimensi kepemimpinan pemberdayaan. Menurut Ahearne dkk., (2005) pemimpin pemberdayaan memiliki empat dimensi: (1) meningkatkan kebermaknaan kerja, (2) mendorong partisipasi dalam pengambilan keputusan, (3) mengungkapkan keyakinan dalam kinerja tinggi, dan (4) memberikan otonomi dari kendala birokrasi. Sedangkan menurut Arnold dan Drasgow (2000) kepemimpinan pemberdayaan terdiri dari lima dimensi yaitu leading by example, coaching, participatif decision making, informing dan show concern.

Amundsen dan Martinsen (2014) mengidentifikasi delapan cerminan perilaku yang mendasari konstruksi kepemimpinan pemberdayaan. Delapan perilaku ini adalah mendelegasikan, mengkoordinasikan dan berbagi informasi, mendorong inisiatif, mendorong fokus tujuan, kemanjuran dukungan, inspirasi, keteladanan, dan bimbingan. Pemimpin yang memberikan kebebasan, mendelegasikan kewenangan dan menjadi teladan inilah yang mengarahkan kepada penciptaan perilaku kreatif karyawan. Sebagai teladan, pemimpin pemberdayaan mampu membuat karyawan menjadi pemimpin dirinya sendiri yang mengarahkan pada penciptaan perilaku kreatif (Amundsen dan Martinsen, 2014). 
Meskipun penelitian terdahulu banyak memberikan dukungan adanya pengaruh yang positif kepemimpinan pemberdayaan terhadap kinerja, tetapi beberapa penelitian memperlihatkan hasil sebaliknya yaitu pemimpin yang memberdayakan tidak signifikan berpengaruh terhadap kreativitas karyawan (Agustina dan Pradana, 2021; Nuzul, 2018). Maka dari itu, masih diperlukan kajian untuk mendukung hubungan kepemimpinan pemberdayaan dengan kreativitas.

Pembahasan faktor yang mempengaruhi kreativitas dan dihubungkan dengan kepemimpinan tidak terlepas dari faktor efikasi diri kreatif. Efikasi diri kreatif yang merupakan kepercayaan diri seseorang bahwa dirinya mampu untuk menampilkan hal-hal yang kreatif (Tierney dan Farmer, 2000). Efikasi diri dipercaya mempengaruhi kreativitas karyawan. Seseorang yang merasa dirinya mampu dan merasa memiliki potensi akan keberhasilan akan lebih mungkin terlibat di dalam penugasan. Karena perasaan percaya diri ini mampu menjadi motivasi untuk berperilaku lebih tinggi ( Haase dkk., 2018). Penelitian meta analisis yang dilakukan oleh Haase dkk. (2018), mempertegas bahwa kreativitas berkaitan dengan efikasi diri seseorang.

Penelitian ini diharapkan memberikan kontribusi pada dukungan literatur kreativitas. Dukungan dalam arah faktor yang mampu meningkatkan kreativitas karyawan dari sisi kepemimpinan dan individual yaitu efikasi diri kreatif karyawan. Selain daripada itu penelitian ini bertujuan untuk menguji dimensi kepemimpinan pemberdayaan yang manakah yang memberikan kontribusi terbesar pada penciptaan kreativitas karyawan.

\section{Metode Penelitian}

Desain penelitian yang dipergunakan adalah desain cross sectional. Populasi penelitian diambil dari 3 perusahaan yang bergerak di bidang jasa keuangan. Dengan total karyawan dari 3 perusahaan berjumlah 265 karyawan. Rumus Slovin dipergunakan untuk mengukur sampel yang terdiri dari 265 karyawan, dengan tingkat kesalahan 5\%. Ukuran sampel didapatkan sejumlah 159. Pengambilan sampel 159 karyawan dari 265 didasarkan dengan teknik probability sampling simple random sampling dengan cara sederhana yaitu pengundian dari nama-nama yang terdapat dalam sampling frame. Dari nama-nama yang keluar tersebut diberikanlah kuesioner untuk di isi. Karena mengedarkannya terpantau, maka didapatkan pengembalian 100\% yaitu sejumlah 159 responden mengembalikan dengan jawaban lengkap.

Pengukuran ketiga variabel dalam penelitian ini mengadaptasi dari kuesioner penelitian-penelitian terdahulu yang diterjemahkan dalam bahasa indonesia. Setelah diterjemahkan dilakukan pengujian awal kepada sejumlah responden untuk melihat hasil validitas dan memastikan bahwa pertanyaan dalam kuesioner dimengerti dan tidak memiliki arti yang berbeda dari kuesioner aslinya. Kepemimpinan pemberdayaan diukur dengan 15 item, diadaptasi dari pengembangan skala Empowering Leadership Questionnaire (ELQ) Arnold dan Drasgow (2000). Kepemimpinan pemberdayaan terdiri dari 5 dimensi yaitu leading by example, coaching, participative decision making, informing dan show concern. Leading by example 
diukur dengan 3 item, coaching diukur dengan 5 item, participative decision making diukur melalui 3 item, informing dengan 3 item dan show concern diukur dengan 5 item. Ukuran kreativitas karyawan mengadaptasi dari 4 item skala yang dikembangkan oleh Jansen (2001). Skala 3 item pengembangan Tierney dan Farmer (2022) dipergunakan untuk mengukur variabel efikasi diri kreatif. Semua ukuran mempergunakan skala tipe likert dengan tingkat persetujuan dari 1 yang menyatakan sangat tidak setuju sampai dengan 5 yang menyatakan sangat setuju.

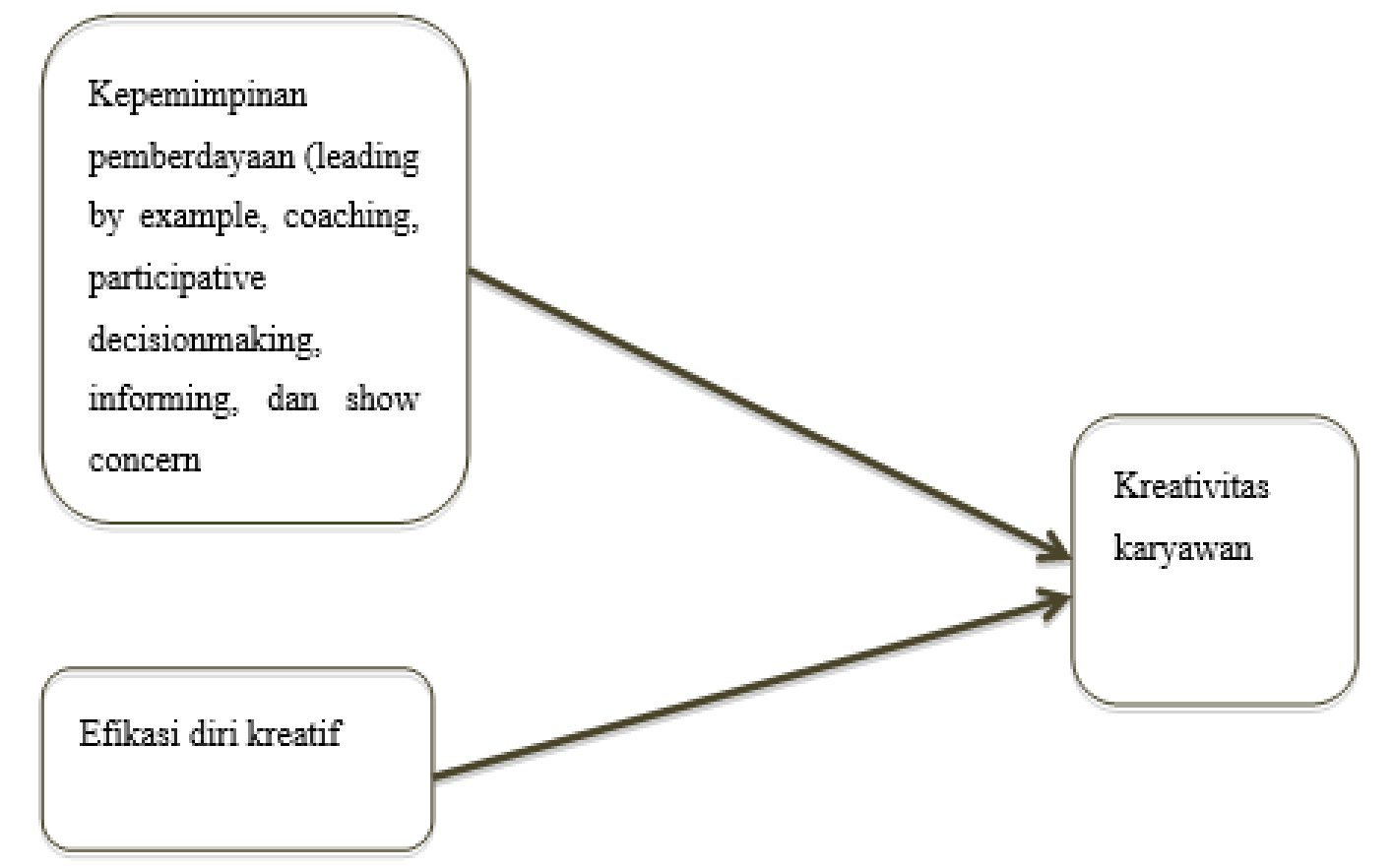

Sumber: Hasil Penelitian (2021)

Gambar 1. Model Penelitian

Pengujian hipotesis mempergunakan teknik analisis regresi berganda. Pengujian instrument, uji validitas dengan confirmatory factor analysis. Uji Reliabilitas mempergunakan Cronbach Alpha. Semua pengujian mempergunakan alat SPSS 26. Penelitian ini mencoba menjembatani dan menjawab kesenjangan penelitian yang ada, dengan memberikan kontribusi model yang mendalam mengenai pengaruh dimensi-dimensi kepemimpinan pemberdayaan pada peningkatan kreativitas karyawan. Model dan hipotesis yang diajukan dalam penelitian ini sebagai berikut:

Hipotesis 1 : Kepemimpinan pemberdayaan berpengaruh terhadap kreativitas karyawan.

Hipotesis 2 : Efikasi diri kreatif berpengaruh terhadap kreativitas karyawan.

Hipotesisi 3a: Dimensi kepemimpinan pemberdayaan leading by example mempengaruhi kreativitas karyawan.

Hipotesisi 3b: Dimensi kepemimpinan pemberdayaan coaching mempengaruhi kreativitas karyawan.

Hipotesisi 3c: Dimensi kepemimpinan pemberdayaan participative decision making mempengaruhi kreativitas karyawan. 
Hipotesisi 3d: Dimensi kepemimpinan pemberdayaan informing mempengaruhi kreativitas karyawan.

Hipotesisi 3d: Dimensi kepemimpinan pemberdayaan show concern mempengaruhi kreativitas karyawan.

\section{Hasil dan Pembahasan}

\subsection{Pengujian Validitas dan Reliabilitas}

Pengujian validitas mempergunakan analisis faktor dengan confirmatory factor analysis memperlihatkan hasil nilai KMO MSA tiap variabel di atas 0,6. Nilai KMO MSA untuk variabel kepemimpinan pemberdayaan sebesar 0,893. Nilai KMO MSA untuk variabel efikasi diri kreatif didapatkan 0,731. Variabel kreativitas karyawan mendapatkan nilai KMO MSA sebesar 0, 801. Semua item memiliki nilai factor loading di atas 0,5 kecuali item no 13 yang merupakan bagian dari dimensi participative decision making dengan nilai loading factor sebesar 0,489 . Tetapi mengingat apabila item ini dikeluarkan akan menurunkan nilai KMO MSA variabel kepemimpinan pemberdayaan dari 0,893 menjadi 0,885 . Begitu pula apabila item 13 dikeluarkan maka nilai cronbach alpha dimensi ini (participative decision making) menurun dari 0,630 menjadi 0,585 . Oleh karena itu berdasar pertimbangan di atas, item 13 tetap diikutkan ke dalam penelitian. Mengingat semua item masuk ke dimensi yang sesuai.

Pengujian Reliabilitas dengan Cronbach Alpha, memperlihatkan hasil variabel memiliki nilai Cronbach Alpha di atas 0,7 , kecuali dimensi participative decision making dengan nilai Cronbach Alpha sebesar 0,630. Berikut nilai Cronbach Alpha berturut-turut, kepemimpinan pemberdayaan 0,916, dimensi leading by example 0,837, coaching 0,883, informing 0,835, show concern 0,833 , efikasi diri kreatif 0,867 dan kreativitas karyawan 0,868 .

\subsection{Pengujian Single Harman Factor}

Penelitian ini mempergunakan desain penelitian cross sectional dan mengumpulkan data dengan kuesioner self rated. Yang mana hal ini sering menimbulkan bias, oleh karena itu, perlu pengujian untuk memperlihatkan bahwa jawaban responden tidak mengandung bias yang berarti. Sehingga interpretasi hasil penelitian bisa dipergunakan dengan baik. Hasil pengujian uji single Harman factor memperlihatkan bahwa jawaban responden dalam penelitian ini tidak mengandung bias yang berarti. Hal ini diperlihatkan dari nilai varians total yang terjelaskan, nilai komponen pertama memiliki persentasi nilai varians yang tidak lebih dari $50 \%$ yaitu $35,158 \%$. Dan jumlah ini tidak lebih dari setengah nya nilai dalam keseluruah komponen yaitu $71,456 \%$.

\subsection{Pengujian Asumsi}

Pengujian asumsi yang dilakukan adalah uji normalitas, heterokedasitisitas dan multikolinieritas. Sedangkan pengujian autokeralasi ditiadakan dikarenakan tidak termasuk dalam pengujian asumsi untuk data penelitian ini. Karena data penelitian ini merupakan data yang dikumpulkan dari kuesioner self rated dan bukan data runtut waktu atau time series. Asumsi data berdistribusi normal diuji dengan pengujian kolomogorov-smirnov. Hasil asym.tot sebesar 0,96 . Hal ini menyatakan data berdistribusi normal, sehingga asumsi normalitas 
terpenuhi untuk melakukan regresi berganda. Heterokedastisitas diuji dengan uji glesjer memberikan hasil terpenuhi asumsi tidak terjadi heterokedastisitas, dengan nilai sig pada pengujian terhadap nilai absolute residualnya tidak ada variabel yang signifikan. Hasil pengujian multikolinieritas memperlihatkan nilai VIF di seputaran 1-2. Hal ini diinterpretasikan tidak terjadi gejala multikolinieritas pada variabel bebas. Semua asumsi terpenuhi sehingga bisa dilanjutkan untuk uji regresi berganda.

\section{4. statistik deskriptif}

Pengujian regresi ataupun pengaruh perlu menampilkan korelasi hubungan antar variabel. Berikut pada tabel 1. Memperlihatkan analisis deskripstif yaitu mean dan standard deviation (SD) serta korelasi zero order antar variabel.

Tabel 1. Mean, Standard Deviation (SD), korelasi zero order

\begin{tabular}{|c|c|c|c|c|c|c|c|c|c|}
\hline Variabel & mean & SD & 1 & 2 & 3 & 4 & 5 & 6 & 7 \\
\hline 1. Kreativitas & 4,030 & 0,672 & 1,000 & & & & & & \\
\hline $\begin{array}{l}\text { 2. Leading by } \\
\text { example }\end{array}$ & 4,340 & 0,683 & $0,511^{*}$ & 1,000 & & & & & \\
\hline 3. Coaching & 3,790 & 0,635 & $0,301^{*}$ & $0,589^{*}$ & 1,000 & & & & \\
\hline 4. Participative & 3,184 & 0,700 & $0,129^{* *}$ & $0,305^{*}$ & $0,476^{*}$ & 1,000 & & & \\
\hline 5. Informing & 4,375 & 0,608 & $0,224^{*}$ & $0,525^{*}$ & $0,540^{*}$ & $0,107^{\star \star \star}$ & 1,000 & & \\
\hline $\begin{array}{l}\text { 6. Show } \\
\text { concern }\end{array}$ & 3,972 & 0,547 & $0,214^{*}$ & $0,587^{*}$ & $0,705^{*}$ & $0,405^{*}$ & $0,507^{*}$ & 1,000 & \\
\hline $\begin{array}{l}\text { 7. Efikasi diri } \\
\text { kreatif }\end{array}$ & 3,407 & 0,739 & $0,612^{*}$ & $0,191^{*}$ & $0,270^{*}$ & $0,123^{* * *}$ & $0,107^{* * *}$ & $0,170^{* *}$ & 1,000 \\
\hline
\end{tabular}

Hasil pada tabel 1 memperlihatkan bahwa semua variabel memiliki korelasi yang signifikan meskipun pada level signifikansi yang berbeda-beda. Korelasi variabel bebas terhadap kreativitas yang paling besar ada di variabel efikasi diri kreatif dengan nilai korelasi 0,612 memperlihatkan kekuatan hubungan pada kategori kuat. Kemudian diikuti dengan variabel leading by example memiliki hubungan yang cukup kuat atau sedang dengan kreativitas dengan nlai korelasi sebesar 0,511 dan sig di 0,00. Dari semua variabel bebas hubungan yang paling lemah dengan kreativitas adalah hubungan participative decision making dengan nilai korelasi 0,129 dengan $p<0,1$.

\subsection{Pengujian Hipotesis}

Pengujian hipotesis dalam penelitian ini dilakukan dengan dua kali pengujian regresi berganda. Pertama untuk menguji hipotesis 1 dan 2, uji regresi berganda pada variabel kepemimpinan pemberdayaan secara unidimensional dan efikasi diri kreatif terhadap kreativitas karyawan. Kedua adalah uji regresi berganda kelima dimensi kepemimpinan pemberdayaan sebagai variabel bebas yaitu leading by example, coaching, participatif decision making, informing dan show concern terhadap kreativitas karyawan.

Model penelitian untuk regresi berganda pada kepemimpinan pemberdayaan yang dianggap unidimensional dan efikasi diri kreatif terhadap kreativitas karyawan merupakan model yang baik. Dapat dilihat pada tabel 2, bahwa nilai F sebesar 11,874 dan signifikan 0,000. Kontribusi kedua variabel dalam menjelaskan varians pengaruh terhadap kreativitas karyawan 
terjelaskan sebesar $41,3 \%$, sedangkan sisa 58,7\% kreativitas karyawan dijelaskan oleh variabel lain di luar penelitian ini. Kontribusi paling banyak dari kedua variabel ini terdapat pada efikasi diri kreatif dengan nilai beta standardized sebesar 0,559. Hal ini berarti efikasi diri kreatif memberikan kontribusi lebih besar dibanding kepemimpinan pemberdayaan (nilai beta standardized 0,222) dalam mempengaruhi kreativitas karyawan. Kontribusi kepemimpinan pemberdayaan dalam mempengaruhi kreativitas hanya sebesar $22,2 \%$ sedangkan efikasi diri mampu mempengaruhi kreativitas karyawan dengan kontribusi $56 \%$.

Tabel 2. Uji regresi berganda terhadap kreativitas karyawan

\begin{tabular}{lcccc}
\hline Variabel & Beta unstandardized & $\begin{array}{c}\text { Beta } \\
\text { standardized }\end{array}$ & $\mathrm{t}$ & sig \\
\hline Kepemimpinan Pemberdayaan & 0,306 & 0,222 & 3,540 & 0,001 \\
\hline Efikasi Diri Kreatif & 0,508 & 0,559 & 8,924 & 0,000 \\
\hline \multicolumn{5}{l}{ Adjusted R ${ }^{2}$} \\
F & 0,413 & & \\
\hline Sumber: Hasil Pengolahan Data (2021) & 56,596 & & 0,000 \\
\hline
\end{tabular}

Tabel 2 juga memperlihatkan hasil pengujian regresi berganda bahwa kepemimpinan pemberdayaan dan efikasi diri kreatif berpengaruh langsung positif signifikan terhadap kreativitas karyawan. Hal ini mendukung hipotesis 1 dan 2. Semakin pemimpin meningkatkan pemberdayaan karyawan maka akan meningkat pula kreativitas karyawan. Hipotesis 1 didukung dengan data, nilai sig sebesar 0,001 dengan nilai beta 0,306 dan nilai $t=3,540$. Hal ini mendukung beberapa penelitian yang mengungkapkan hasil serupa bahwa pelaksanaan kepemimpinan pemberdayaan akan meningkatkan perilaku kreativitas karyawan (Alfaris dan Zakiy, 2021; Fitriani dan Wulansari, 2018; Martono, Wulansari dan Khoirudin, 2020). Kepemimpinan pemberdayaan atau empowering leadership memiliki peran yang kuat dalam meningkatkan kreativitas bawahan (Arshad dkk., 2021). Proses peningkatan kreativitas karyawan oleh pemimpin pemberdayaan dipercaya melalui adanya peningkatan kepercayaan bawahan terhadap pemimpin (Fitriani dan Wulansari, 2018), dan akhirnya meniru apa yang pemimpin kerjakan sehingga mampu memberikan rasa pemberdayaan dan kepercayaan diri untuk peningkatan kreativitas (Azliyanti, Jatmiko, dan Utami, 2019).

Begitupula apabila seseorang semakin memiliki rasa percaya diri dalam kreativitas maka karyawan juga akan semakin kreatif, mendukung hipotesis 2. Dukungan untuk hipotesis 2 , terlihat pada hasil pengaruh efikasi diri kreatif terhadap kreativitas mendapatkan nilai sig sebesar 0,000. Hasil ini memberikan arti terbukti signifikan berpengaruh positif dengan nilai beta 0,508 dan $t$ sebesar 8,924. Hal ini mendukung pernyataan bahwa efikasi diri kreatif (creative self efficacy) seseorang yang tinggi akan meningkatkan perilaku kreatif (Sultika dan Haritijasti, 2017). Penciptaan kreativitas karyawan dihasilkan dari kemampuan efikasi diri kreatif karyawan, efikasi diri tinggi maka karyawan semakin mampu berperilaku kreatif (Kempa dan Eric, 2020). Hasil penelitian ini juga mendukung hasil penelitian meta analisis yang dilakukan oleh Haase dkk., (2018) seseorang yang memiliki efikasi diri kreatif yang tinggi akan merasa 
mampu dan percaya diri sehingga meningkatkan motivasi untuk berperilaku lebih kreatif (Azliyanti, Jatmiko, dan Utami, 2019).

Tabel 3. Uji regresi berganda dimensi kepemimpinan pemberdayaan

\begin{tabular}{|c|c|c|c|c|}
\hline Variabel & Beta unstandardized & $\begin{array}{c}\text { Beta } \\
\text { standardized }\end{array}$ & $\mathrm{t}$ & sig \\
\hline Leading by example & 0,567 & 0,576 & 6,245 & 0,000 \\
\hline Coaching & 0,136 & 0,129 & 1,165 & 0,246 \\
\hline Participatif decision making & $-0,030$ & $-0,031$ & $-0,384$ & 0,701 \\
\hline Informing & $-0,062$ & $-0,056$ & $-0,632$ & 0,528 \\
\hline Show concern & $-0,213$ & $-0,174$ & $-1,680$ & 0,095 \\
\hline Adjusted $\mathrm{R}^{2}$ & 256 & & & \\
\hline $\mathrm{F}$ & 11,874 & & & 0,000 \\
\hline
\end{tabular}

Pada tabel 3, menjelaskan bahwa dari kelima dimensi kepemimpinan pemberdayaan hanya satu dimensi yaitu leading by example yang terbukti signifikan dengan nilai sig $0,000<0,05$. Meskipun model menunjukkan sebagai model yang bagus dengan tingkat sig $F$ $0,000<0,05$, dengan nilai $F$ sebesar 11,874 . Tetapi kelima dimensi kepemimpinan pemberdayaan hanya menjelaskan varians sebesar $25,6 \%$ pada pengaruh kreativitas karyawan. Dan $74,4 \%$ varians lainnya di luar dari variabel penelitian ini menjelaskan kreativitas karyawan. Hasil menunjukkan bahwa hipotesis 3a didukung dan hipotesis 3b, 3c, 3d, 3e tidak didukung dengan data. Dimensi coaching, participative decision making, informing, dan show concern tidak signifikan mempengaruhi kreativitas karyawan.

Dimensi leading by example didefinisikan sebagai seorang pemimpin yang mampu menjadi model, panutan bagi para bawahan (Arnold dan Drasgow, 2000). Pemimpin yang merupakan panutan yang mana bawahan melihat sebagai model yang perlu diikuti, ketika pemimpin memberikan contoh untuk kemandirian melalui pemberdayaan, maka akan meningkatkan kemandirian bawahan, meningkatkan pemberdayaan diri bawahan dan juga kemampuan mempimpin diri sendiri dari para bawahan (Amundsen dan Martinsen, 2014). Karyawan mampu memimpin diri sendiri untuk berkarya, memberdayakan dirinya sendiri mengikuti panutan pemimpinnya akan meningkat pula kreativitas dirinya (Amundsen dan Martinsen, 2014; Sultika dan Haritijasti, 2017).

\section{Kesimpulan}

Kepemimpinan pemberdayaan dan efikasi diri kreatif mempengaruhi pada penciptaan kreativitas karyawan. Dari kelima dimensi kepemimpinan pemberdayaan hanya dimensi leading by example yang meningkatkan kreativitas karyawan. Penelitian ini menggunakan setting penelitian perusahaan perbankan, penelitian ke depan sebaiknya melakukan penelitian pada setting yang berbeda-beda. Begitu pula desain penelitian yang dipergunakan dalam penelitian ini adalah cross sectional maka penelitian ke depan sebaiknya mempergunakan desain longitudinal, dan penilaian kreativitas bukan dari self rated, sehingga mampu memperlihatkan peningkatan dan hubungan kreativitas yang lebih dalam. Implikasi penelitian bagi perusahaan, 
memberikan saran bagi perusahaan yang ingin meningkatkan terciptanya kreativitas karyawan maka perlu menerapkan kepemimpinan pemberdayaan dan melakukan program yang mampu meningkatkan kemandirian dan memberdayakan karyawan. Begitu pula melaksanakan program yang mampu meningkatkan rasa percaya diri karyawan dalam kreativitas semisal dengan memberikan pelatihan motivasi, pelatihan untuk terus berkreativitas, memberikan sarana dan prasarana yang mendukung aktivitas berkreasi.

\section{Daftar Pustaka}

Agustina, T., \& Pradana, A. (2021, January 31). Empowering Leadership dalam Membentuk Employee Creativity. Jurnal Bisnis Dan Manajemen, 17(1), 13-26. https://doi.org/https://doi.org/10.23960/jbm.v17i1.182

Ahearne, M., Mathieu, J., \& Rapp, A. (2005). To Empower or Not to Empower Your Sales Force? An Empirical Examination of the Influence of Leadership Empowerment Behavior on Customer Satisfaction and Performance. Journal of Applied Psychology, 90(5), 945-955. https://doi.org/10.1037/0021-9010.90.5.945

Alfaris, B., \& Zakiy, M. (2021). Affective Commitment As A Mediation Variables Effect Of Empowering Leadership On Employee Creativity. JEBIS (Jurnal Ekonomi dan Bisnis Islam) I JOURNAL OF ISLAMIC ECONOMICS AND BUSINESS, 7(2), 250 - 266. doi:http://dx.doi.org/10.20473/jebis.v7i2.26685

Amundsen, S., \& Martinsen, Ø. L. (2015). Linking Empowering Leadership to Job Satisfaction, Work Effort, and Creativity: The Role of Self-Leadership and Psychological Empowerment. Journal of Leadership \& Organizational Studies, 22(3), 304-323. https://doi.org/10.1177/1548051814565819

Arnold, J.A., Arad, S., Rhoades, J.A., \& Drasgow, F. (2000). The empowering leadership questionnaire: the construction and validation of a new scale for measuring leader behaviors. Journal of Organizational Behavior, 21(3). https://doi.org/10.1002/(SICl)10991379(200005)21:3<249::AID-JOB10>3.0.CO;2-\%23

Arshad, M., Yu, C.K., Qadir, A., Ahmad, W., \& Xie, C. (2021) The moderating role of knowledge sharing and mediating role of employee creative self-efficacy on the association of empowering leadership and employee creativity. International Journal of Management PracticeVol, 14(6). Retrieved from https://www.inderscienceonline.com/doi/abs/10.1504/IJMP.2021.118940

Azliyanti, E., Jadmiko, P., \& Utami, W. (2019). Peran Pemediasi Efikasi Diri Kreatif Pada Hubungan Antara Persepsi Terhadap Kepemimpinan Transformasional Pada Kreativitas Karyawan. Relevance: Journal of Management and Business, 2(2). doi:https://doi.org/10.22515/relevance.v2i2.1913

Fitriani, Y., \& Wulansari, N. (2018). Impact of Empowering Leadership on Employee Creativity by Motivation to Learn and Trust in Leader as a Mediation. Management Analysis Journal, 7(2), 244-253. https://doi.org/10.15294/maj.v7i2.25141

Haase, J., Hoff, E.V., Hanel, P.H.P \& Innes-Ker, A. (2018). A MetaAnalysis of the Relation between Creative Self-Efficacy and Different Creativity Measurements, Creativity Research Journal, 30(1), 1-16, 10.1080/10400419.2018.1411436

Hughes, D.J.,Lee, A., Tian, A.w., Newman, A., \& Legood, A. (2018). Leadership, creativity, and innovation: A critical review and practical recommendations, The Leadership Quarterly, 29(5), 549-569.https://doi.org/10.1016/j.leaqua.2018.03.001.

Kempa, S., \& Eric, S. (2020). Creative Performance: Dampak Work Environment Dan Creative Self-Efficacy (Studi Kasus di PT. Putra Mojo Maju Jaya Abadi. JRMSI - Jurnal Riset Manajemen Sains Indonesia, 11(2), 282-299. https://doi.org/10.21009/JRMSI.011.2.05

Luthans, F. (2011). Organizational behavior an evidence based approach (12 ed.). new york, usa: McGrawwHill Companies, Inc.

Martono, S., Wulansari, N.A., \& Khoiruddin, M. (2020). IOP Conf. Series: Earth and Environmental Science 485. 10.1088/1755-1315/485/1/012060 
Nuzul, A. (2018). Hubungan Antara Empowering Leadership, Creative Self Efficacy Dan Employee Creativity Serta Dampaknya Terhadap Kinerja Karyawan. Jurnal Ilmu Manajemen, 6(2). Retrieved from https://core.ac.uk/download/pdf/230763739.pdf

Sari, S. R. (2017). Organizational Ambidexterity: Ketanggguhan yang dibutuhkan untuk keberlangsungan kinerja organisasi masa depan. Jurnal Riset Manajemen dan Bisni (JRMB) , 2 (3), 433-438.

Sultika, B., \& Hartijasti, Y. (2017). Faktor-Faktor Yang Memengaruhi Kreativitas Dan Orientasi Inovasi Di Tempat Bekerja (Studi Kasus Di Perum Bulog). Jurnal Riset Bisnis dan Manajemen Tirtayasa, 1(2). http://dx.doi.org/10.48181/jrbmt.v1i2.3036

Thawil, S. M., \& Sari, S. R. (2018). Kesuksesan Implementasi Inovasi Oganisasi. Jurnal Riset Manajemen dan Bisnis (JRMB) Fakultas Ekonomi UNIAT , 3 (2), 175-182.

Zhang, S., Ke, X., Wang, X-H.F., \& Liu, J. (2018). Empowering leadership and employee creativity: A dual-mechanism perspective. Journal of Occupational and Organizational Psychology, 91(4), 896-917. https://doi.org/10.1111/joop.12219 